\title{
PENGARUH MOTIVASI DAN KEPUASAN KERJA TERHADAP KINERJA TENAGA KEPENDIDIKAN SMK NEGERI DI KABUPATEN LOMBOK BARAT
}

\author{
Zaenal Abidin ${ }^{1}$, Agus Ramdani ${ }^{2}$, Untung Waluyo ${ }^{3}$ \\ Program Studi Magister Administrasi Pendidikan ${ }^{123}$ \\ Program Pascasarjana Universitas Mataram ${ }^{123}$ \\ Email: zaenal.narmada@gmail.com
}

\begin{abstract}
Abstrak: Tujuan penelitian ini adalah untuk mengetahui pengaruh motivasi dan kepuasan kerja terhadap kinerja tenaga kependidikan SMK Negeri di Kabupaten Lombok Barat. Penelitian ini merupakan penelitian kuantitatif dengan metode ex-post facto. Populasi penelitian ini adalah seluruh tenaga kependidikan SMK Negeri di Kabupaten Lombok Barat yang berjumlah 304. Sampel penelitian berjumlah 46 tenaga kependidikan yang diambil dengan teknik random sampling. Hasil penelitian adalah: 1) terdapat pengaruh motivasi sebesar 27,7\% terhadap kinerja tenaga kependidikan SMK Negeri di Kabupaten Lombok Barat, 2) terdapat pengaruh kepuasan kerja sebesar 13,1\% terhadap kinerja tenaga kependidikan SMK Negeri di Kabupaten Lombok Barat, 3) terdapat pengaruh motivasi dan kepuasan kerja secara bersama-sama sebesar 28,0\% terhadap kinerja tenaga kependidikan SMK Negeri di Kabupaten Lombok Barat. Dengan demikian, dapat disimpulkan bahwa semakin baik motivasi dan kepuasan kerja, kinerja tenaga kependidikan SMK Negeri di Kabupaten Lombok Barat akan semakin meningkat.
\end{abstract}

Kata Kunci: Motivasi, Kepuasan Kerja, dan Kinerja Tenaga Kependidikan

\begin{abstract}
The purpose of this study was to determine the effect of motivation and job satisfaction on education personnel performance at Vocational High School in West Lombok regency. This research is a quantitative with of ex-post facto method. The population of this research is all education personnel at Vocational High School in West Lombok regency amounted 304. These samples included 46 of education personnel were taken by random sampling technique. The results of the research are: 1) there is significant motivation effect amounted $27.7 \%$ on the education personnel performance at Vocational High School in West Lombok regency, 2) there are significant job satisfaction effect amounted $13.1 \%$ on the education personnel performance at Vocational High School in West Lombok regency, 3) there are the influence of motivation and job satisfaction together amounted $28.0 \%$ on the education personnel performance at Vocational High School in West Lombok regency. Thus, it can be concluded that the better motivation and job satisfaction, education personnel performance at Vocational High School in West Lombok regency will be increase.
\end{abstract}

Keywords: Motivation, Job Satisfaction, and Education Personnel Performance. 


\section{PENDAHULUAN}

Sekolah sebagai lembaga pendidikan merupakan lembaga yang berperan penting dalam menghasilkan Sumber Daya Manusia (SDM) yang memiliki kualifikasi dan kompetensi tinggi. Karenanya, sekolah dituntut untuk mampu memberikan kontribusi yang positif terhadap pembangunan dan peningkatan SDM di Indonesia. Sebagai lembaga pendidikan yang didirikan pemerintah dan pihak swasta, sekolah diharapkan menjadi lembaga yang menyiapkan tenaga terdidik melalui kemampuan intelektual, potensi, spiritual, kepribadian dan sosial dalam membentuk manusia Indonesia seutuhnya. Oleh karena itu sekolah perlu dikelola secara efektif dan efisien untuk mencapai tujuan tersebut.

\section{Undang-Undang}

Sistem

Pendidikan Nasional No. 20 Tahun 2003

Pasal 3 menyatakan bahwa Pendidikan Nasional berfungsi sebagai wahana untuk mengembangkan kemampuan dan pelayanan teknis untuk menunjang proses pendidikan pada satuan pendidikan. Sebagai bagian dari keseluruhan sistem manajemen pendidikan di sekolah, tenaga kependidikan yaitu pegawai tata usaha menempati kedudukan yang strategis dalam membantu penyiapan kegiatan proses belajar mengajar di sekolah. Akan tetapi, sejauh ini peran mereka tidak banyak diketahui oleh masyarakat luas. Karenanya, peneliti merasa perlu untuk mengangkat persoalan ini sebagai bahan kajian.

Saat ini, masalah mutu dan kinerja pegawai tata usaha sekolah di Lombok Barat, pada kenyataannya masih belum maksimal dan luput dari pantauan banyak orang sehingga pegawai tata usaha belum memberikan kontribusi yang signifikan terhadap peningkatan mutu pendidikan. Harus disadari bahwa motivasi, kepuasan kerja dan kinerja membentuk watak serta peradaban bangsa yang bermartabat. Dalam rangka mencerdaskan kehidupan bangsa, arah pendidikan nasional ditujukan untuk mengembangkan potensi peserta didik agar mereka menjadi manusia yang beriman dan bertakwa kepada Tuhan Yang Maha Esa, berakhlak mulia, sehat, berilmu, cakap, kreatif, mandiri, dan menjadi warga negara yang demokratis serta bertanggung jawab.

Untuk mencapai cita-cita luhur di atas, diperlukan kerja keras dan sinergi antarkomponen SDM di Sekolah. Pada dasarnya, setiap komponan SDM di Sekolah, seperti guru (pendidik), pegawai tata usaha, siswa, lingkungan pendidikan, manajemen sekolah, dan kurikulum sangat berpengaruh terhadap kinerja Sekolah. Undang-Undang Sistem Pendidikan Nasional No. 20 Tahun 2003 Pasal 39 menyatakan bahwa tenaga kependidikan bertugas melaksanakan administrasi, pengelolaan, pengembangan, pengawasan, dan pegawai tata usaha merupakan beberapa faktor yang mempengaruhi mutu sebuah sekolah. Sejauh ini, upaya peningkatan mutu dan kinerja pegawai tata usaha sekolah masih nampak kurang mendapat perhatian. Upaya peningkatan kualitas pendidikan hanya difokuskan pada permasalahan guru, peningkatan kinerja kepala sekolah dan kurikulum siswa yang senantiasa berubah-ubah. Dalam praktek sehari-hari di sekolah, jarang dijumpai seorang pegawai tata usaha mendapatkan kesempatan mengikuti pelatihanpelatihan, diklat, maupun seminar untuk meningkatkan kapasitas dan kapabilitas mereka.

Kondisi di atas perlu mendapat perhatian dari berbagai pihak pemangku kepentingan sekolah. Sekolah, sebagai suatu sistem terdiri atas berbagai komponen yang saling berhubungan dan saling mempengaruhi antara satu dengan yang lainnya. Bila ada satu komponen 
saja yang terganggu maka bukan tidak mungkin sistem tersebut juga akan turut terganggu. Dalam realitanya memang tidak jarang sistem sebuah sekolah menjadi bermasalah karena faktor mutu, motivasi pegawainya, kepuasan kerja dan kinerja tata usaha yang masih rendah.

Maharjan (2012) menyatakan habwa, kinerja adalah suatu hasil yang dicapai karena termotivasi dengan pekerjaan dan merasa puas dengan pekerjaan yang mereka lakukan. Viswesvaran \& Ones (dalam Jimoh, 2008) menyatakan bahwa kinerja karyawan merupakan tindakan, perilaku dan hasil yang dapat diukur di mana karyawan terikat atau yang dilakukan karyawan yang berhubungan dengan tujuan organisasi dan berkontribusi pada tujuan organisasi. Steven, et al (2010) menunjukkan bahwa, orientasi tujuan kinerja seseorang adalah untuk menghindari kekhawatiran tentang tidak membuat kesalahan yang mengurangi kepuasan kerja mereka bahkan ketika orang tersebut memiliki motivasi intrinsik yang kuat. ini berarti bahwa, organisasi harus mendorong karyawan untuk mengasumsikan strategi orientasi tujuan organisasi tersebut.

Sejauh ini di berbagai SMKN yang ada di Kabupaten Lombok Barat ditemukan berbagai persoalan kinerja pegawai sekolah non-pendidik. Permasalahan yang ada saat ini diantaranya adalah:

1) Masih banyak ditemukannya pegawai tata usaha yang belum atau bahkan tidak memiliki kemampuan, kecakapan atau keahlian yang memadai untuk mengerjakan tugastugas mereka dengan standar performa yang baik dan memuaskan.

2) Masih banyak pegawai tata usaha yang belum biasa mengoperasikan komputer dengan baik untuk urusan administrasi tata usaha sekolah, padahal hampir semua urusan administrasi sekolah sekarang menggunakan komputer.

3) Pekerjaan tata usaha sekolah yang masih semrawut, seperti pengarsipan surat yang tidak rapi, data-data sekolah yang tidak lengkap maupun tidak up to date.

4) Masih rendahnya disiplin, loyalitas dan tanggung jawab pegawai tata usaha dalam merencanakan dan melaksanakan tugas-tugas mereka sebagai pegawai tata usaha sekolah.

5) Masih belum tercerminnya pelayanan prima yang diberikan pegawai tata usaha kepada siswa, orang tua dan masyarakat.

6) Masih belum nampak kecerdasan emosional, spiritual, dan bahkan juga kecerdasan intelektual pegawai tata usaha dalam memecahkan berbagai permasalahan serta dalam berinteraksi di lingkungan.

Terkait dengan gambaran awal kondisi kinerja di atas, hasil laporan dari Dinas Pendidikan dan Kebudayaan Kabupaten Lombok Barat yang kemudian dituangkan dalam Renstra Tahun 2015, saat ini dapat digambarkan sebagai berikut: (1) Belum memadainya sumber daya Aparatur yang profesional dan sarana prasarana. (2) Belum terlaksananya reformasi birokrasi sesuai dengan isyarat perundang-undangan. Gambaran ini mengindikasikan bahwa masalah kinerja Pegawai Negeri Sipil (PNS) di lingkungan sekolah-sekolah di Lombok Barat masih terkendala dan belum berjalan dengan maksimal.

Metode audit kinerja PNS di lingkungan sekolah sejauh ini tidak pernah dianggap bermasalah. Model penilaian DP3 atau istilah barunya sekarang SKP (Sasaran Kerja Pegawai) saat ini, dianggap satu-satunya alat ukur kinerja pegawai yang valid dan terpercaya. Karena cara penilaian yang cendrung kompromistis, hasil penilaian 
kinerja karyawan cendrung menyenangkan pihak yang dinilai, melalui pemberian nilai yang sangat baik meskipun dalam kenyataannya hasil penilaian itu berlawanan dengan kinerja yang dipraktekkan oleh pegawai seharihari. Penilaian seperti ini tentunya tidak memenuhi rasa keadilan dan penghargaan terhadap mereka yang betul-betul bekerja dengan keras. Hasil penilaian DP3 sekarang ini menggambarkan bahwa orang yang rajin bekerja kinerjanya sama dengan orang malas. Tidak ada perbedaan signifikan antara mereka yang rajin dan yang malas, baik dari segi pemberian insentif, penerimaan gaji, kenaikan pangkat dan sebagainya. Oleh karena itu, kepuasan kerja yang riil dirasakan oleh pegawai tata usaha khususnya dan PNS umumnya belum pernah terungkap ke permukaan dalam kasus-kasus pelanggaran disiplin PNS karena cara mengukurnya tidak seperti yang semestinya.

Berdasarkan PP Nomor 53 Tahun 2010, setiap PNS termasuk tenaga pendidik dan Pegawai tata usaha wajib dievaluasi kinerjanya, akan tetapi evaluasi kinerja berdasarkan DP3 atau SKP saat ini belum mampu mencerminkan kondisi riil dengan baik. Apabila kita melihat data sekolah yang ada di Lombok Barat, kita akan sangat terkesan dengan prestasi, kinerja dan disiplin pegawai sekolah karena hampir semuanya termasuk dalam kategori sangat baik. Akan tetapi, kita akan terkejut apabila kita melihat kenyataan yang ada di lapangan. Sampai saat ini, di SMK Negeri Kabupaten Lombok Barat masih banyak ditemukan pegawai yang meninggalkan tugas pada jam-jam kerja, tidak masuk kerja tanpa alasan yang jelas, bolos, dikeluhkan oleh masyarakat karena layanan yang kurang maksimal, dan sebagainya. Hal ini jelas menunjukkan bahwa evaluasi PNS saat ini belum menyentuh kinerja riil di lapangan sebagaimana yang diamanatkan oleh undang-undang.

Permasalan kinerja tenaga kependidikan tersebut, tentu haruslah menjadi perhatian bersama berbagai pihak agar reformasi birokrasi di tingkat sekolah dapat diwujudkan. Salah satu faktor yang bisa meningkatkan kerja pegawai tersebut adalah pembenahan tata kelola lembaga dan pemberian motivasi kerja yang baik kepada mereka. Peran motivasi pegawai tata usaha, baik intrinsik maupun ekstrinsik, sangat penting bagi terciptanya layanan kerja pegawai tata usaha yang profesional. Karena motivasi inilah yang menentukan perilaku orang-orang untuk giat bekerja, atau dengan kata lain, perilaku merupakan cerminan yang paling sederhana dari motivasi. Terkait dengan hal ini, Sutrisno (2015:115) menyebutkan bahwa motivasi adalah suatu faktor yang mendorong seseorang untuk melakukan suatu aktivitas tertentu. Oleh karena itu, motivasi sering kali diartikan pula sebagai faktor pendorong perilaku seseorang. Setiap aktivitas yang dilakukan oleh seseorang pasti memiliki suatu faktor yang mendorong aktivitas tersebut. Faktor pendorong dari seseorang untuk melakukan sesuatu aktivitas tertentu pada umumnya adalah kebutuhan serta keinginan orang tersebut. Mangkunegara

(2015:93) menyatakan bahwa motivasi adalah kondisi yang menggerakkan karyawan atau pegawai mencapai tujuan dari motif tindakannya. Dalam hal ini, motif dapat diartikan sebagai suatu dorongan kebutuhan dalam diri pegawai yang perlu dipenuhi agar pegawai tersebut dapat menyesuaikan diri terhadap lingkungannya. Dengan demikian, motivasi merupakan kondisi yang mampu menggerakkan seseorang untuk melakukan sesuatu demi tercapainya tujuan yang sudah direncanakan sebelumnya. 
Motivasi dan kepuasan kerja adalah seperti satu mata uang dengan dua sisi. Apabila motivasi pegawai dapat dipacu, maka ini akan mendorong munculnya kepuasan kerja. Karenanya, kepuasan kerja bagi pegawai tata usaha juga sangat diperlukan untuk meningkatkan kinerja mereka. Dalam hal ini, kepuasan kerja dapat didefinisikan sebagai kesesuaian antara harapan seseorang dengan imbalan yang disediakan. Pada umumnya, kepuasan kerja pegawai tata usaha erat kaitannya dengan prestasi kerja, disiplin, dan kualitas kerja. Pada pegawai tata usaha yang puas terhadap pekerjaannya, kinerjanya cenderung meningkat dan berdampak positif terhadap peningkatan mutu layanan pendidikan. Sejalan dengan hal ini, Sutrisno (2015:79) mengemukakan kepuasan kerja adalah keadaan emosional yang menyenangkan atau tidak menyenangkan bagi para karyawan memandang pekerjaan mereka.

Robbins (2001) mendefinisikan kepuasan kerja sebagai sikap umum seseorang terhadap pekerjaan yang dilakukan. Pekerjaan membutuhkan interaksi/hubungan dengan rekan kerja dan atasan, mematuhi peraturan dan kebijakan organisasi, memenuhi standar kinerja, hidup dengan suasana kerja yang sering kali kurang dari ideal. Menurut Zainal, dkk. (2014:620), kepuasan kerja adalah kondisi yang menggambarkan seseorang atas perasaan atau sikapnya yang senang atau tidak senang, puas atau tidak puas, dalam bekerja. Dengan demikian, kepuasan kerja merupakan tingkatan rasa puas individu terhadap imbalan yang setimpal dari bermacammacam aspek situasi pekerjaan dari organisasi tempat mereka bekerja.

Dole and Schroeder dalam (Koesmono, 2005) kepuasan kerja dapat di definisikan sebagai perasaan dan reaksi individu terhadap lingkungan pekerjaannya. Nuzsep (2004) mengemukakan bahwa ada hubungan positif yang signifikan antara kepuasan kerja dengan produktivitas kerja. Hal ini menunjukkan bahwa, semakin tinggi kepuasan kerja yang diterima seorang karyawan, semakin tinggi pula produktivitas kerjanya. Cecilia (2006) menyimpulkan hasil penelitiannya bahwa, kepuasan kerja memiliki hubungan yang signifikan terhadap kinerja. Dengan demikian, kepuasan kerja seseorang akan mempengaruhi produktivitas kerja karyawan dalam suatu organisasi tersebut. Semakin baik kepuasan seseorang dalam suatu organisasi, maka kinerja seseorang tersebut akan semakin baik.

Dari uraian di atas, kesimpulan sementara dapat diajukan bahwa kepuasan kerja adalah cerminan sikap, perasaan dan kecintaan seseorang terhadap pekerjaannya. Kepuasan kerja tercermin pada sikap positif karyawan terhadap pekerjaan dan segala sesuatu yang dihadapi di lingkungan kerjanya. Karyawan yang tidak memperoleh kepuasan kerja cenderung tidak akan pernah mencapai kepuasan psikologis dan akhirnya akan timbul sikap atau tingkah laku negatif. Sikap seperti ini pada gilirannya akan menimbulkan perasaan frustasi pada diri pegawai. Sebaliknya pegawai yang mendapat kepuasan kerja yang tinggi cenderung akan bekerja dengan maksimal, penuh semangat, aktif dan berupaya menciptakan prestasi-prestasi lain yang lebih baik daripada pegawai yang tidak memperoleh kepuasan kerja (Sutrisno, 2015:79).

Berdasarkan permasalahan yang saya paparkan di atas maka penelitian ini mencoba mengkaji "Pengaruh Motivasi dan Kepuasan Kerja terhadap Kinerja Tenaga Kependidikan SMK Negeri di Kabupaten Lombok barat" 


\section{METODE PENELITIAN}

Penelitian ini akan dilaksanakan di di SMK Negeri Kabupaten Lombok Barat Provinsi Nusa Tenggara Barat. Penelitian ini menggunakan pendekatan ex-post facto artinya peneliti tidak menggunakan perlakuan terhadap variabel-variabel penelitian, melainkan mengkaji faktafakta yang telah terjadi. Populasi dalam penelitian ini adalah seluruh tenaga kependidikan SMK Negeri Kabupaten Lombok Barat yang berjumlah 304 orang. sampel penelitian ini adalah 46 orang atau $15 \%$ dari jumlah keseluruhan populasinya.

Instrumen penelitian yang dipakai sebagai alat ukur variabel penelitian adalah angket model skala Likert dengan 5 (lima) pilihan jawaban. Sugiyono (2014) mengatakan bahwa skala tersebut dapat digunakan untuk mengukur sikap, pendapat dan persepsi seseorang atau sekelompok orang tentang fenomena tertentu. Pemilihan instrumen kuesioner (angket) model skala Likert berdasarkan pada pertimbangan bahwa dengan instrumen ini jawaban responden dapat diperoleh secara memadai dan memudahkan dalam pengolahan/mendeskripsikan hasilnya serta sesuai dengan tujuan yang hendak dicapai dalam penelitian ini.

Instrumen yang baik dalam penelitian adalah instrumen yang valid dan reliabel. Uji validitas instrumen dilakukan melalui 2 tahapan yaitu validitas ahli dan validitas isi. Sugiyono (2014:353) menjelaskan bahwa pada setiap instrumen terdapat butir-butir (item) pertanyaan atau pernyataan yang harus diujicobakan setelah dikonsultasikan kepada para ahli kemudian dianalisis dengan analisis item.

Cara untuk mengukur validitas isi yaitu menggunakan rumus korelasi product moment dengan angka kasar, sebagai berikut (Arikunto, 2003:213):

$$
r_{x y}=\frac{N \sum X Y-\left(\sum X\right)\left(\sum Y\right)}{\left.\sqrt{\left\{N \sum X^{2}-\left(\sum X\right)^{2}\right\}\left\{N \sum Y^{2}-\left(\sum Y^{2}\right)^{2}\right.}\right)}
$$

Setelah harga koefisien validitas tiap isi diperoleh, perlu dilakukan uji signifikansi untuk mengukur keberartian koefisien korelasi berdasarkan distribusi kurva normal dengan menggunakan statistik uji-t dengan persamaan:

$$
t=r_{x y} \sqrt{\frac{N-2}{1-r_{x y}^{2}}}
$$

Untuk mengetahui reliabilitas seluruh tes digunakan rumus Alfa Cronbach sebagai berikut:

$r_{11}=\left(\frac{n}{n-1}\right)\left(1-\frac{\sum \sigma_{1}^{2}}{\sigma_{1}^{2}}\right.$

Perhitungan validitas dan reliabilitas instrumen dengan persamaan di atas menggunakan program SPSS versi 17.0 for Windows.

Teknik analisis data yang dipergunakan dalam penelitian ini adalah analisis regresi, baik regresi sederhana maupun regresi ganda. Langkah berikutnya adalah melaksanakan uji persyaratan analisis data yang meliputi uji normalitas, homogenitas, multikolinieritas, dan autokorelasi, dan dilanjutkan dengan pengujian hipotesis.

Pengaruh secara kuantitatif antara variabel bebas $\mathrm{X}$ terhadap variabel terikat $\mathrm{Y}$ dihitung dengan menganalisis bentuk persamaan regresi linier sederhana, dengan model persamaan:

$\boldsymbol{y}=\boldsymbol{a}+\boldsymbol{b} \boldsymbol{X}+\varepsilon$

Keterangan:

a $\quad=$ konstanta regresi

$\mathrm{b}=$ Koefisien regresi

$\mathrm{X}_{\mathrm{i}} \quad=$ Variabel bebas

$\varepsilon \quad=$ Kesalahan prediksi

Untuk mengetahui seberapa besar pengaruh motivasi dan kepuasan kerja secara bersama-sama terhadap kinerja tenaga 
kependidikan, maka dihitung juga dengan menganalisis bentuk regresi ganda dengan persamaan:

$y=a+b_{1} X_{1}+b_{2} X_{2}+\varepsilon$

Keterangan:

$$
\begin{array}{ll}
\mathrm{a} & =\text { konstanta regresi } \\
\mathrm{b}_{1}, \mathrm{~b}_{2} & =\text { Koefisien regresi } \\
\mathrm{X}_{1}, \mathrm{X}_{2} & =\text { Variabel Bebas } \\
\boldsymbol{\varepsilon} & =\text { Kesalahan prediksi }
\end{array}
$$

\section{HASIL PENELITIAN DAN PEMBAHASAN}

Berdasarkan hasil analisis desfriptif, diperoleh data seperti yang ditunjukkan pada Gambar berikut.

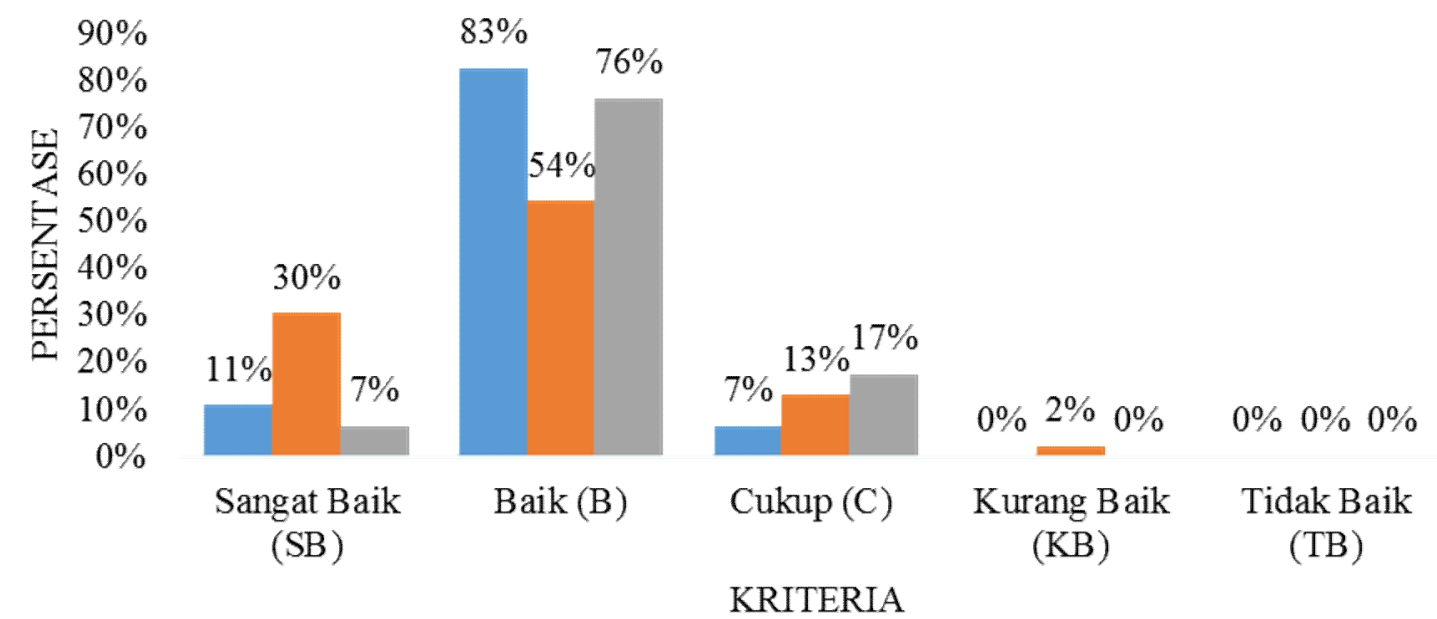

\section{$\square$ MOTIVASI $\approx$ KEPUASAN KERJA $\quad$ KINERJA TENAGA KEPENDIDIKAN}

Gambar 1: Hasil Analisis Deskripsi Data Penelitian

Berdasarkan Gambar 1 di atas, dapat disimpulkan bahwa ketiga variabel penelitian ini yaitu motivasi, kepuasan kerja, dan kinerja tenaga kependidikan SMK Negeri di Kabupaten Lombok Barat berada pada kategori baik karena grafiknya menunjukkan persentase di atas $50 \%$ pada kategori baik pada ketiga variabel penelitian.

Sebelum analisis data, terlebih dahulu dilakukan uji normalitas, homogenitas, multikolinieritas, dan autokorelasi. Dari hasil uji yang dilakukan menunjukkan bahwa semua data telah memenuhi syarat untuk dilakukan uji hipotesis dengan menggunakan uji statistik. Hasil uji statistik untuk melihat pengaruh masingmasing variabel bebas terhadap bariabel terikat yang dapat dirangkum dalam Tabel 1 sebagai berikut. 


\begin{tabular}{lcccccc}
\hline \multirow{2}{*}{ Variabel } & \multicolumn{3}{c}{ Koefisien Regresi } & & \multirow{2}{*}{ Sig. } & \multirow{2}{*}{$\mathrm{R}^{2}$} \\
\cline { 2 - 6 } & Konstanta & $\begin{array}{c}\text { Koefisien Regresi } \\
\text { b } \text { thitung }\end{array}$ & & & \\
\hline Motivasi & 43.231 & 0.368 & 4.108 & 0,000 & 0.277 \\
\hline Kepuasan Kerja & 55.108 & 0.220 & 2.576 & 0.013 & 0.131 \\
\hline
\end{tabular}

Berdasarkan Tabel 1 di atas untuk motivasi diperoleh nilai $t_{\text {hitung }}$ sebesar 4,108 dan nilai signifikan diperoleh sebesar 0,000 lebih kecil daripada 0,05 (Sig. < 0,05), sehingga terdapat pengaruh yang signifikan motivasi terhadap kinerja tenaga kependidikan SMK Negeri di Kabupaten Lombok Barat. Berdasarkan hasil analisis diperoleh koefisien regresi motivasia $b$ sebesar 0,368 dan konstanta (intercept) $a$ sebesar 43,231. Dengan demikian, pengaruh motivasi terhadap kinerja tenaga kependidikan SMK Negeri di Kabupaten Lombok Barat ditunjukkan oleh persamaan $\widetilde{\mathrm{Y}}=43,231+0,368 X_{1}$. Artinya bahwa perubahan satu unit persepsi pada peubah motivasi diikuti oleh perubahan kinerja tenaga kependidikan SMK Negeri di Kabupaten Lombok Barat sebesar 0,368 unit dengan intercept sebesar 43,321. Motivasi berpengaruh signifikan sebesar 27,7\% terhadap kinerja tenaga kependidikan SMK Negeri di Kabupaten Lombok Barat.

Dari hasil pengujian hipotesis dapat disimpulkan bahwa terdapat pengaruh yang signifikan motivasi terhadap kinerja tenaga kependidikan di Kabupaten Lombok Barat. Kesimpulan tersebut menunjukkan bahwa semakin baik motivasi, maka kinerja tenaga kependidikan SMK Negeri di Kabupaten Lombok Barat juga semakin baik. Artinya, untuk meningkatkan kinerja tenaga kependidikan SMK Negeri di Kabupaten Lombok Barat, sangat penting untuk memperhatikan motivasi mereka dalam bekerja.

Hasil penelitian ini sejalan dengan hasil penelitian yang dilakukan oleh
Darmika dan Natajaya (2014), dan Suwardi (2011) bahwa motivasi memiliki pengaruh positif terhadap peningkatan kinerja karyawan. Hasil penelitian ini juga sejalan dengan penelitian oleh Muogbo (2013), Maharjan (2012), Peter dan Bram (2009), Gungor (2011) yang membuktikan bahwa motivasi berpengaruh positif dan signifikan terhadap kinerja karyawan. Hasil penelitian sebelumnya tersebut, menjadi penguat hasil penelitian ini yaitu, upaya meningkatkan kinerja tenaga kependidikan SMK Negeri di Kabupaten Lombok Barat dapat dilakukan dengan cara meningkatkan motivasi mereka dalam bekerja. Untuk itu, indikator dari motivasi yang digunakan dalam penelitian ini perlu diperhatikan.

Kontribusi motivasi terhadap peningkatan kinerja tenaga kependidikan SMK Negeri di Kabupaten Lombok Barat $27,7 \%$. Artinya hahwa, kinerja tenaga kependidikan di SMKN Kabupaten Lombok Barat dipengaruhi oleh motivasi sebesar 27,7\%. Sutrisno (2015:109) menyatakan bahwa motivasi adalah suatu faktor yang mendorong seseorang untuk melakukan suatu aktivitas tertentu, oleh karena itu motivasi sering kali diartikan pula sebagai faktor pendorong perilaku seseorang untuk bertindak atau berbuat sesuatu. Dengan demikian, upaya peningkatan motivasi kepada tenaga kependidikan SMK Negeri di Kabupaten Lombok Barat dapat menjadi pendorong kepada mereka untuk dapat meningkatkan kinerja mereka menjadi lebih baik. 
Berdasarkan hasil pengolahan data penelitian, upaya meningkatkan motivasi pada tenaga kependidikan SMK Negeri di Kabupaten Lombok Barat dapat dilakukan dengan jalan memberikan imbalan yang setimpal kepada tenaga kependidikan SMK Negeri di Kabupaten Lombok Barat. Hal ini ditunjukkan berdasarkan jumlah skor maksimal dari jawaban responden tentang motivasi kerja ditunjukkan pada butir No. 2 yang menyatakan "sekolah memberikan imbalan yang setimpal kepada tenaga kependidikan yang memiliki prestasi kerja yang baik.

Pada intinya, dalam meningkatkan motivasi kepada tenaga kependidikan SMK Negeri di Kabupaten Lombok Barat dapat dilakukan dengan memperhatikan indikator pada penelitian ini yaitu: 1) prestasi kerja, 2) pengembangan diri, 3) pekerjaan itu sendiri, 4) pengakuan, 5) penghargaan, dan 6) keamanan kerja.

Berkaitan dengan prestasi kerja, sekolah harus benar-benar memperhatikan tenaga kependidikan yang memiliki prestasi yang baik, sekolah harus memberikan penghargaan dan imbalan agar prestasi kerjanya semakin meningkat. Pengembangan diri kepada tenaga kependidikan juga menjadi perhatian penting dalam meningkatkan motivasi tenaga kependidikan di SMK Negeri di Kabupaten Lombok Barat. Seorang karyawan tentu akan berusaha meningkatkan kinerjanya apabila diberikan kesempatan untuk mengembangkan dirinya dalam bekerja. Selain itu, pengakuan atas pekerjaan tenaga kependidikan SMK Negeri di Kabupaten Lombok Barat juga dapat meningkatkan motivasi mereka dalam bekerja yang tentunya akan berdampak pada peningkatan kinerja mereka. Seorang karyawan akan merasa pekerjaannya yang dilakukan benar- benar bermanfaat untuk orang lain apabila pekerjaannya mendapatkan pengakuan dari atasan atau teman sebayanya, sehingga mereka akan terus berusaha untuk meningkatkan kinerja mereka dalam bekerja.

Keamanan dalam bekerja juga menjadi faktor penting dalam meningkatkan motivasi tenaga kependidikan dalam bekerja. Seorang karyawan akan merasa nyaman dan tentram dalam bekerja apabila keamanan kerja yang ada dilingkunga tempat kerjanya terjaga dengan baik, sehingga seorang karyawan dalam hal ini tenaga kependidikan SMK Negeri di Kabupaten Lombok Barat akan merasa tenang juga dalam berusaha meningkatkan kinerja mereka dalam bekerja.

Berdasarkan Tabel 1 di atas untuk kepuasan kerja diperoleh nilai $t_{\text {hitung }}$ sebesar 2,576 dan nilai signifikan diperoleh sebesar 0,013 lebih kecil daripada 0,05 (Sig. $<0,05)$, sehingga terdapat pengaruh yang signifikan kepuasan kerja terhadap kinerja tenaga kependidikan SMK Negeri di Kabupaten Lombok Barat. Berdasarkan hasil analisis diperoleh koefisien regresi motivasia $b$ sebesar 0,220 dan konstanta (intercept) $a$ sebesar 55,108. Dengan demikian, pengaruh kepuasan kerja terhadap kinerja tenaga kependidikan SMK Negeri di Kabupaten Lombok Barat ditunjukkan oleh persamaan $\hat{\mathrm{Y}}=55,108+0,220 X_{1}$. Artinya bahwa perubahan satu unit persepsi pada peubah kepuasna kerja diikuti oleh perubahan kinerja tenaga kependidikan SMK Negeri di Kabupaten Lombok Barat sebesar 0,220 unit dengan intercept sebesar 55,108. Kepuasan kerja berpengaruh signifikan sebesar 13,1\% terhadap kinerja tenaga kependidikan SMK Negeri di Kabupaten Lombok Barat.

Hasil pengujian hipotesis kedua dapat disimpulkan bahwa terdapat pengaruh yang signifikan kepuasan kerja 
terhadap kinerja tenaga kependidikan SMK Negeri di Kabupaten Lombok Barat. Kesimpulan tersebut menunjukkan bahwa semakin baik kepuasan kerja, maka kinerja tenaga kependidikan SMK Negeri di Kabupaten Lombok Barat juga semakin baik. Artinya bahwa, untuk meningkatkan kinerja tenaga kependidikan SMK Negeri di Kabupaten Lombok Barat, selain motivasi sangat penting untuk memperhatikan kepuasan kerja mereka dalam bekerja.

Hasil penelitian ini sejalan dengan hasil penelitian yang dilakukan oleh Dewi (2014), dan Risqi (2015) bahwa kepuasan kerja berpengaruh positif terhadap kinerja karyawan. Dengan demikian, dapat disimpulkan bahwa selain motivasi kerja, kinerja tenaga kependidikan SMK Negeri di Kabupaten Lombok Barat dapat ditingkatkan dengan memperhatikan kepuasan kerja mereka dalam bekerja.

Selain itu, hasil penelitian ini sejalan dengan hasil penelitian yang dilakukan oleh beberapa peneliti sebelumnya diantaranya : Helena dan Almigo (2004), Anthony et al. (2006), Tang et al. (2014), Pushpakumari (2008) yang menyatakan bahwa kepuasan kerja berpengaruh positif terhadap kinerja karyawan.

Zainal, dkk. (2014:620)

menyatakan bahwa kepuasan kerja adalah kondisi yang menggambarkan seseorang atas perasaan atau sikapnya yang senang atau tidak senang, puas atau tidak puas, dalam bekerja. Kepuasan kerja merupakan tingkatan rasa puas individu terhadap imbalan yang setimpal dari bermacam-macam aspek situasi pekerjaan dari organisasi tempat mereka bekerja. Dengan demikian, tenaga kependidikan SMK Negeri di Kabupaten Lombok Barat bisa meningkatkan kinerja mereka dalam bekerja apabila mereka merasa puas atau senang dalam bekerja.

Meningkatkan kepuasan kerja tenaga kependidikan SMK Negeri di Kabupaten Lombok Barat dapat dilakukan dengan memperhatikan indikator kepuasan kerja yang digunakan dalam penelitian ini yaitu: 1) upah atau gaji, 2) ketentraman kerja, 3) kondisi kerja, dan 4) kesempatan untuk maju. Kontribusi kepuasan kerja terhadap kinerja tenaga kependidikan SMK Negeri di Kabupaten Lombok Barat sebesar 13,1\%.

Pengaruh motivasi dan kepuasan kerja secara bersama-sama terhadap kinerja tenaga kependidikan SMK Negeri di Kabupaten Lombok Barat di analisis menggunakan regresi ganda. Hasil analisis ditunjukkan pada Tabel 2 sebagai berikut:

Tabel 2. Pengaruh Variabel $\mathrm{X}_{1}$ dan $\mathrm{X}_{2}$ secara bersama-sama terhadap Variabel $\mathrm{Y}$

\begin{tabular}{lcccc}
\hline \multicolumn{1}{c}{ Model } & Koefisien Regresi & $\mathrm{F}_{\text {hitung }}$ & Sig. & $\mathrm{R}^{2}$ \\
\hline Konstan $(a)$ & 43.674 & 8.341 & 0.001 & 0.280 \\
\hline Motivasi $(b 1)$ & 0.406 & & & \\
\hline Kepuasan Kerja $(b 2)$ & 0.044 & & & \\
\hline
\end{tabular}

Berdasarkan Tabel 2 di atas, diperoleh nilai $\mathrm{F}_{\text {hitung }}$ sebesar 8,341 dan diperoleh nilai signifikan diperoleh sebesar 0,001 lebih kecil daripada 0,05 (Sig. <0,05). Dengan demikian, dapat disimpulkan bahwa terdapat pengaruh yang signifikan motivasi dan kepuasan kerja secara bersama-sama terhadap kinerja tenaga kependidikan SMK Negeri di Kabupaten Lombok Barat. Motivasi kerja dan kepuasan kerja secara bersamasama berpengaruh signifikan sebesar 
$28 \%$ terhadap kinerja tenaga kependidikan SMK Negeri di Kabupaten Lombok Barat.

Berdasarkan hasil analisis, diperoleh koefisien arah regresi bl sebesar 0,406, arah regseri b2 sebesar 0,044 , dan konstanta (intercept) a sebesar 43,674. Dengan demikian, pengaruh motivasi dan kepuasan kerja secara bersama-sama terhadap tenaga kependidikan SMK Negeri di Kabupaten Lombok Barat ditunjukkan oleh persamaan $\hat{\mathrm{Y}}=43,674+0,406 X_{1}+0,044 X_{2}$.

Artinya bahwa: 1) Perubahan satu unit persepsi pada motivasi $\left(\mathrm{X}_{1}\right)$ dan faktor kepuasan kerja dianggap konstan, akan diikuti oleh perubahan kinerja tenaga kependidikan (Y) sebesar 0,406 unit pada intercept sebesar 43,676. 2) Perubahan satu unit pada epuasan kerja $\left(\mathrm{X}_{2}\right)$ dan faktor motivasi dianggap konstan, akan diikuti oleh perubahan kinerja tenaga kependidikan (Y) sebesar 0,044 pada intercept sebesar 43,676.

Meningkatkan kinerja tenaga kependidikan SMK Negeri di Kabupaten Lombok Barat merupakan hal yang sangat penting untuk dilakukan, karena dengan kinerja mereka yang baik akan membantu sekolah dalam meningkatkan mutu pendidikan. Banyak faktor yang dapat dilakukan dalam meningkatkan kinerja tenaga kependidikan SMK Negeri di Kabupaten Lombok Barat, namun dalam penelitian ini ada dua faktor penting yang dapat meningkatkan kinerja mereka yaitu motivasi dan kepuasan kerja. Kontribusi motivasi dan kepuasan kerja terhadap kinerja tenaga kependidikan SMK Negeri di Kabupaten Lombok Barat sebesar 28\%. Persentase tersebut menunjukkan hasil yang cukup baik yang dapat membuktikan bahwa motivasi dan kepuasan kerja memiliki peran yang cukup besar dalam meningkatkan kinerja tenaga kependidikan SMK Negeri di Kabupaten Lombok Barat.

Selain motivasi dan kepuasan kerja, kinerja tenaga kependidikan juga dipengaruhi oleh faktor lain. Sedarmayanti (2009:72-76) menyatakan bahwa, faktor-faktor yang mempengaruhi kinerja antara lain: (1) sikap mental (motivasi kerja, disiplin kerja, etika kerja); (2) pendidikan; (3) ketrampilan; (4)manajemen kepemimpinan; hubungan industrial pancasila; (6) tingkat penghasilan; (7) gizi dan kesehatan; (8) jaminan sosial; (9) lingkungan dan iklim kerja; (10) sarana produksi; (11) teknologi. Dengan demikian bahwa, untuk meningkatkan kinerja karyawan, tidak cukup dengan hanya memperhatikan motivasi dan kepuasan kerja saja tetapi masih ada faktor lain yang bisa dijadikan sebagai pendorong dalam meningkatkan kinerjanya.

Hasil penelitian ini menunjukkan bahwa, motivasi memiliki kontribusi yang lebih besar dalam meningkatkan kinerja tenaga kependidikan SMK Negeri di Kabupaten Lombok Barat dibandingkan kepuasan kerja. Hal ini menunjukkan bahwa indikator motivasi seperti: prestasi kerja, pengembangan diri, pekerjaan itu sendiri, pengakuan, penghargaan, dan keamanan kerja memiliki peran yang lebih besar dalam meningkatkan kinerja tenaga kependidikan SMK negeri di Kabupaten Lombok Barat.

Meskipun motivasi memiliki peran yang lebih besar dibandingkan kepuasan kerja dalam meningkatkan kinerja tenaga kependidikan SMK Negeri di Kabupaten Lombok Barat, pada intinya kedua faktor tersebut merupakan hal yang penting dalam meningkatkan kinerja tenaga kependidikan SMK Negeri di Kabupaten Lombok Barat. 


\section{KESIMPULAN}

Berdasarkan hasil penelitian ini, maka dapat disimpulkan beberapa hal sebagai berikut:

1. Motivasi berpengaruh positif dan signifikan terhadap kinerja tenaga kependidikan SMK Negeri di Kabupaten Lombok Barat. Hal ini menunjukkan bahwa semakin baik dan meningkat motivasi yang diberikan terhadap tenaga kependidikan SMK Negeri di Kabupaten Lombok Barat, maka kinerja mereka akan semakin meningkat.

2. Kepuasan kerja berpengarurh positif dan signifikan terhadap kinerja tenaga kependidikan SMK Negeri di Kabupaten Lombok Barat. Hal ini menunjukkan bahwa semakin tinggi

\section{DAFTAR PUSTAKA}

Almigo, Nuzsep, 2004. Hubungan Antara Kepuasan Kerja dengan Hubungan Produktivitas Kerja Karyawan, Fakultas Psikologi Universitas Bina Darma, Palembang. Vol 1 No 1, pp. 50-60

Anthony, Scott, Gravelle Hugh, Steven Simoens, Chris Bojke and Bonnie Sibbald. 2006. Job Satisfaction and Quitting Intentions: A Structural Model of British General Practitioners. British Journal of Industrial Relations. Vol. 44, No. 3, p. 519-540

Arikunto. 2003. Prosedur Penelitian Suatu Pendekatan Praktek. Jakarta: Rineka Cipta

Cecilia, Engko. 2006, Pengaruh Kepuasan Kerja Terhadap Kinerja Individual. Makalah dan meningkat kepuasan kerja tenaga kependidikan SMK Negeri di Kabupaten Lombok Barat, maka kinerja mereka akan semakin meningkat dalam menghasilkan output kinerja.

3. Motivasi dan kepuasan kerja secara bersama-sama berpengaruh positif dan signifikan terhadap kinerja tenaga kependidikan SMK Negeri di Kabupaten Lombok Barat. Hal ini menunjukkan bahwa semakin baik dan meningkat motivasi bersama dengan kepuasan kerja yang diberikan terhadap tenaga kependidikan SMK Negeri di Kabupaten Lombok Barat, maka kinerja mereka akan semakin meningkat.

pada Simposium Akuntansi pada 23-26 Agustus, Padang

Darmika, I Md. Karba \& Natajaya, Md. Yudana. 2014. Kontribusi Locus of Control, Iklim Kerja, dan Motivasi Kerja Terhadap Kinerja Guru Pasca Sertifikasi Pada GuruGuru SMP di Kecamatan Bangli, Kabupaten Bangli. eJournal Program Pascasarjana Universitas Pendidikan Ganesha Program Studi Administrasi Pendidikan. 5 (1).

Dewi, C. Charisma. 2014. Pengaruh Stres Kerja Dan Kepuasan Kerja Terhadap Kinerja Karyawan Pada Bagian Tenaga Penjualan UD Surya Raditya Negara. e-Journal Bisma Universitas Pendidikan Ganesha Jurusan Manajemen. Vol. 2. 
Gungor, Pinar. 2011. The Relationship Between Reward Management System and Employee Performance with the Mediating Role of Motivation: A Quantitative Study on Global Banks. Okan University, Istanbul, 34722 Turkey. Vol.1. No 2.pp.15101520

Jimoh, A. M., 2008, Emotional Labour, Conscientiousness and Job Tenure as Predictors of Job Performance Among University Administrative Workers in Southwestern Nigerian, International Journal of African \& African American Studies. 7, (2), pp.111-123

Koesmono, H. Teman. 2005. Pengaruh Budaya Organisasi Terhadap Motivasi dan Kepuasan Kerja Serta Kinerja Karyawan Pada Sub Sektor Industri Pengolahan Kayu Skala Menengah di Jawa Timur. Jurnal Manajemen \& Kewirausahaan. 7, (2). 171188

Maharjan, Sarita. 2012. Association between Work Motivation and Job Satisfaction of College Teachers Administrative and Management Review Vol. 24, No 2, pp..45-55.

Mangkunegara. 2015. Manajemen Sumber Daya Manusia Perusahaan. PT Remaja Rosdakarya. Bandung.

Muogbo, U.S. 2013. The Impact of Employee Motivation on Organisational Performance
(A Study Of Some Selected Firms In Anambra State Nigeria).

Nuzsep, Almigo. 2004. Hubungan Antara Kepuasan Kerja dengan Hubungan Produktivitas Kerja Karyawan. Fakultas Psikologi Universitas Bina Darma, Palembang. Vol 1 No 1, pp. 50-60

Peter, Kisink, Bram Steijn. 2009. Public Service Motivation and Job Performance of Public sector employees in the Netherland. Internatonal review of Administrative, science, vol 75, No 1.pp. 35-52

Pushpakumari, M. D. 2008. The Impact of Job Satisfaction on Job Performance :An Empirical Analysis. Forum city, Sri Langka. Vol. 9 No1. June. pp..89-105

Risqi, R. Ovita. 2015. Analisis pengaruh kepuasan kerja terhadap kinerja karyawan Dengan pendekatan kansei engineering perusahaan XYZ. AGRITECH, Vol. 35 (1).

Robbins, Stephen P. 2001. Organizational Behavior (9th ed). New Jersey: Prentice Hall.

Sedarmayanti. 2009. Sumber Daya Manusia dan Produktivitas Kerja. Bandung: Mandar Maju

Steven, Brown \& Tobias, Huning. 2010. Intrinsic Motivation and Job Satisfaction: The Intervening Role of Goal Rientation 
Proceedings of The Academy Of Organizational Culture. Communications and Conflict 15 (1) Columbus State University. New Orleans. pp. 1-5

Sugiyono. 2014. Metode Penelitian Pendidikan Pendekatan Kuantitatif, Kualitatif, dan $R \& D$. Bandung: Alfa Beta.

Sutrisno, Edy. 2015. Manajemen Sumber Daya Manusia. Kencana. Jakarta.

Suwardi. 2011. Pengaruh Motivasi Kerja, Kepuasan Kerja, Dan Komitmen Organisasional Terhadap Kinerja Pegawai (Studi Pada Pegawai Setda
Kabupaten Pati). Jurnal Analisis Manajemen Vol. 5 No. 1.

Tang, T. L. P., Luna-Arocas, R., Sutarso, T., dan Tang, D. S. H. 2004. Does the love of money moderate and mediate the income-pay satisfaction relationship? Journal of Managerial Psychology, Vol 2, pp.111-135

Zainal, V. Rivai, Ramly, Mansyur. Mutis, Thoby. Afafah, Willy. 2014. Manajemen Sumber Daya Manusia Untuk Perusahaan: Dari Teori ke Praktik Edisi ketiga. PT Rajawali Pers. Jakarta. 